Електронне наукове фахове видання "Ефективна економіка" включено до переліку наукових фахових видань України з питань економіки (Категорія «Б», Наказ Міністерства освіти і науки України від 11.07.2019 № 975) www. economy.nayka.com.ua | № 5, 2020| 28.05.2020 p.

DOI: $10.32702 / 2307-2105-2020.5 .201$

УДК 379.8

A. Taranenko

Postgraduate student, Kyiv National University of Trade and Economics

ORCID ID: 0000-0001-7213-5199

\title{
ECONOMIC IMPACT OF EVENTIVE MEASURES ON DESTINATION
}

\author{
А. П. Тараненко, \\ аспірант, Київський національний торговельно-економічний університет

\section{ЕКОНОМІЧНИЙ ВПЛИВ ІВЕНТИВНИХ ЗАХОДІВ НА ТУРИСТИЧНУ ДЕСТИНАЦІЮ}

The article analyzes the necessity to study the economic impact of eventive measures on the host tourist destination. The nature of the economic impact of eventive measures on the destination is revealed. The significance of eventive measures for tourism development in certain destinations is substantiated. The basic directions of estimation of economic impact of events on a destination are presented: determination of direct influence; taken into account in conjunction with the direct effect also of the indirect and induced multiplier effect; other formats for determining the costeffectiveness of events. It is argued that in order to determine the direct impact of eventive measures on the economy of the destination (city, region), first of all, we need to determine the return on investments, taking into account the cost of business structures for the event and the amount of funds raised in the charity for the event. It is proved that when calculating the revenue of a tourist destination from an event, it is necessary to take into account the tourists expenses for transport and other services related to the specifics of the event. At the same time, the author proposes to take into account the outflow of funds from the destination at the expense of the cost of the prize fund, imported goods and more when calculating the multiplier effect. The problem of possible negative economic impact of eventive measures for local residents was also updated. The need for a comprehensive approach to assessing the impact of eventive measures on a destination, taking into account socio-cultural, environmental, technological impacts, is generalized. The need for a comprehensive approach to assessing the impact of eventive measures on a destination, taking into account socio-cultural, environmental, technological impacts, is generalized.The direct effect is determined based on the amount of economic activity revenues directly related to the eventive measures. These indicators are determined because of surveys or estimates, taking into account the number of visitors and the cost of the main components of an eventive product.

The dynamics, magnitude and impact of the eventive measures growth have contributed to the emergence of scientific researches regarding their economic impact on the host destination.

У статті проаналізовано необхідність дослідження економічного впливу івентивних заходів на приймаючу туристичну дестинацію. Розкрито природу економічного впливу івентивних заходів на туристичну дестинацію. Представлено основні напрями оцінки економічного впливу івентивних подій на туристичну дестинацію: визначення прямого впливу; врахування 
y сукупності із прямим впливом також $i$ непрямого та індукованого на основі мультиплікаційного ефекту; інші формати визначення економічної ефективності івентів. Аргументовано щуо для визначення прямого впливу івентивних заходів на економіку дестинації (міста, регіону), в периу чергу провести визначення рентабельності інвестицій $з$ урахуванням витрати бізнес структур структур на проведення івенту та обсягу залучених кошти в рамках благодійності на проведення івентивного заходу. Доведено, шуо під час розрахунку доходу туристичної дестинації від проведення івентивного заходу необхідно враховувати витрати туристів на транспорт та на інші послуги, пов'язані із специфікою даного заходу. Водночас, автором запропоновано при розрахунку мультиплікачійного ефекту враховувати «виток» кочтів із дестинації за рахунок витрат на призовий фонд, імпортовані товари та інше. Актуалізована проблема можливого негативного економічного впливу івентивних заходів для місцевих жителів дестинації. Узагальнено необхідність комплексного підходу до оцінки впливу івентивних заходів на дестинацію із врахуванням сочіально-культурних, екологічних, технологічних наслідків. На наш погляд, в епоху розумово-інтелектуального розвитку туризм, крім неактивного відпочинку, перейшов щзе й на дієве знаряддя пізнання довколишнього світу $і$ міжкультурного діалогу. Прагнення, сполучаючи відпочинок та освіту, збагатити власний світогляд, понуривши себе у коловорот життя в інших країнах світу, примножити свою сочіальну мобільність $i$ професійну універсальність, стають основною мотивацією нової генерації туристів. Заплановані події є певним видом тимчасового феномену, і кожна окрема подія є по своєму унікальною, оскільки події розглядаються як перетин встановлених подій, людей та системи управління.

Keywords: tourism; event; economic impact; effect

Ключові слова: туризм; івент; економічний вплив; ефект.

Problem statement. The civil challenges posed by the unprecedented unforeseen force majeure of the spread of coronovirus disease have greatly affected the global tourism sector. However, as stated in the documents of the Unites Nations World Tourism Organization (UNWTO), with proper and effective planning, organization of activities, this sector is able to recover in a very short time. They even determine an indicative parameter - 10 months, for which world tourism can increase its capacity to pre-crisis indicators level [ ]. Moreover, according to experts of the tourism sector, the effective economic recovery is related to the offers of innovative products on the market that can attract a wide range of consumers. Such products certainly include eventive measures that, due to the scale of the activity, reach of a large audience and the resonance of events, are able to shape the performance of destinations in various manifestations: economic, social, technological, environmental, etc. Certainly, an important aspect is to determine the economic impact of eventive measures on the host destinations.

Recent research and publications analysis. The dynamics, magnitude and impact of the eventive measures growth have contributed to the emergence of scientific researches regarding their economic impact on the host destination. It is believed that the first publications in this area were the works of Davidson L. S. \& Schaffer W.A. (1980), which outlined the conceptual framework for assessing economic impact, highlighting the economic consequences associated with a particular event and work of John S. Marsh (1984) on the economic results of a youth hockey tournament.

Noteworthy are the studies of recent years of evaluating the benefits and economic impact of eventive tourism conducted by B. Burgan, T. Mules, N. Hodur and F. Leistritz. Of particular note are the studies regarding mega-event activities (large-scale events at world or regional level), which result in a dynamic increase in the number of tourist arrivals to the destination. There is a scientific interest in the world in determining the impact of mega-sporting activities on a host destination. Thus, A.K. Rose and M. Spiegel evaluated the effect of the Summer and Winter Olympics between 1950 and 2006 to trade flows, determining the gravity equation for two-way exports. Based on this gravity model, J. Fourie and M. Santana-Gallego evaluated the effects of six mega-sports events: the Summer and Winter Olympics, the FIFA World Cup, CricketWorld Cup, RugbyWorld Cup and the Lions Tour. However, the achievements of domestic scientists do not fully reflect these issues. Therefore, the urgency of the problem and the need for its coverage, taking into account the theoretical and practical content, determines the research in this direction.

Purpose statement. The purpose of the article is to substantiate the importance and to determine the economic impact of eventive measures on the host tourist destination.

Presentation of basic material. Eventive measures for the development of tourism have an undeniable impact, since even in the absence of a powerful natural or cultural and historical potential of the tourist destination, the 
event can attract a significant amount of tourists. Moreover, the eventive measures contribute to the activation of other types of economic activity: transport, trade, restaurant business, and other services. Particular attention should be paid to the involvement of small business, including folk and souvenir crafts, gastronomic industries, advertising promotion campaigns. At the same time, it is worth noting the development of the social component, including employment. However, the most important result of the event is economic one.

The economic impact of eventive measures on the destination can be considered from different points of view: 1) attracting investment for organizing and conducting events; 2) direct expenses of tourists and their impact on the economy of the destination; 3) the aggregate of direct and indirect expenses of tourists and their impact on the economy of the destination; 4) the compounding effect associated with the possible accumulation of economic benefits.

In the studies of scientists N. Bobina [2], V. Goncharov [3] regarding the economic impact of eventive measures on the destination, the following main results are determined: the growth of gross domestic product, jobs, and tax revenues. Moreover, these results are generated at the expense of tourists. The study of N. Hodur and F. Leistritz $[13$, p. 66] draws attention to the fact that the economic benefit (cost-effectiveness) of the eventive measures relates to the flow of funds from three different sources: a) construction of facilities (if applicable); b) object/event operations; c) consumer expenses associated with attending and participating in events (Figure 1).

\begin{tabular}{|c|c|c|}
\hline \multicolumn{2}{|c|}{$\begin{array}{c}\text { Economic benefit (cost-effectiveness) from eventive } \\
\text { measures }\end{array}$} & eventive \\
\hline$\nabla$ & $\frac{1}{v}$ & 7 \\
\hline $\begin{array}{l}\text { Construction of facilities } \\
\text { (if applicable) }\end{array}$ & Object/event operations & $\begin{array}{l}\text { Consumer costs associated } \\
\text { with attending and } \\
\text { participating in events }\end{array}$ \\
\hline \multirow[t]{2}{*}{$\begin{array}{l}\text { Cost of: } \\
\text { design, construction of } \\
\text { structures; } \\
\text { building materials; } \\
\text { subcontracts of local } \\
\text { small and mid-sized } \\
\text { enterprises and more } \\
\quad \text { Funding Sources: } \\
\text { - state budget; } \\
\text { - local budget; } \\
\text { - financing by private } \\
\text { entities; } \\
\text { - sponsorship } \\
\text { - etc. }\end{array}$} & 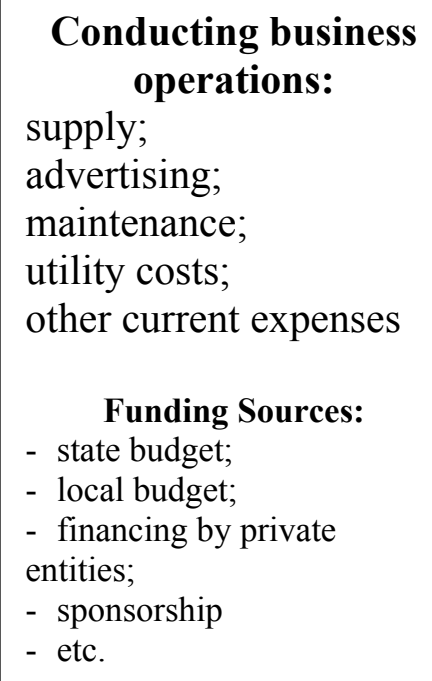 & $\begin{array}{l}\text { Consumer expenses: } \\
\text { accommodation, dining, } \\
\text { purchase of necessary } \\
\text { goods and services, } \\
\text { expenses related to } \\
\text { attending or } \\
\text { participating in an event, } \\
\text { tickets } \\
\quad \text { Funding Sources: } \\
\text { - own savings; } \\
\text { - financing by private } \\
\text { entities; } \\
\text { - sponsorship }\end{array}$ \\
\hline & \multicolumn{2}{|c|}{$\begin{array}{l}\text { Participants costs (sellers, direct participants } \\
\text { of events): } \\
\text { business trip; } \\
\text { salary; } \\
\text { accommodation, dining, purchase of necessary } \\
\text { goods and services, other current expenses } \\
\text { (necessary equipment, etc.) } \\
\text { Funding Sources: } \\
\text { - own savings; } \\
\text { - financing by private entities; } \\
\text { - sponsorship }\end{array}$} \\
\hline
\end{tabular}

Fig. 1. Economic benefit/cost-effectiveness of the eventive measures Source: Developed by author under [13] 
There are different approaches to determining the cost-effectiveness of eventive measures.

1. The direct impact of tourists expenses during an event on the development of a destination. The direct effect is determined based on the amount of economic activity revenues directly related to the eventive measures. These indicators are determined because of surveys or estimates, taking into account the number of visitors and the cost of the main components of an eventive product. In addition, using the methodology proposed by O. Alekseeva [1, p. 5] and refining it, it is possible to determine the direct impact of eventive measures on the economy of the destination (city, region), first of all, by determinig the return on investments (ROI):

$$
\mathrm{ROI}=(\mathrm{GM}-(\text { Ед }+ \text { Еб }+ \text { Ебл })):(\text { Ед }+ \text { Еб }+ \text { Ебл })
$$

where: Ед are costs of state (local) structures for the event;

Еб are expenses of business structures for carrying out an event;

Ебл are raised funds in the framework of charity for the event;

$\mathrm{GM}$ is the revenue received from tourists as part of an event visit.

Accordingly, the result is a percentage ratio in which: zero means a break-even program of activities, and negative indicators mean a loss of investment. Moreover, it is most expedient to calculate the GM indicator for an event by means of a survey questionnaire. In the survey, you can determine the average tourist expenses, while adding to the list of costs (author's note: specified in the mentioned methodology) the tourists expenses for transport and other services related to the specifics of the event. Thus, the calculation of the tourist destination revenue from an event is as follows (2):

where:

$$
\mathrm{GM}=(\mathrm{TEa}+\mathrm{TEd}+\mathrm{TEs}+\mathrm{TEe}+\mathrm{TEt}+\mathrm{TEa}) \times \mathrm{m}
$$

GM is the revenue from the event;

TEa are the average tourist expenses for accommodation;

TEd are the average tourist expenses for dining;

TEs are the average tourist expenses for souvenirs;

TEe are the average tourist expenses for excursions;

TEt are the average tourist expenses for transport;

TEa are the average tourist expenses for other services related to the specifics of the event

$\mathrm{m}$ is the total number of consumers (tourists) who have visited the event.

When conducting a survey of tourists, the amount of average expenses is determined taking into account the probability of purchasing a particular service:

where:

$$
\mathrm{v}=1: \mathrm{n} \times 100,0 \%
$$

$\mathrm{v}$ is the probability of purchasing a particular service/product;

1 is the number of surveyed tourists who have used a particular service/ product;

$\mathrm{n}$ is the number of tourists surveyed during the poll.

Thus, the formula of return on investments during an event takes the following form:

where:

$$
\mathrm{ROI}=((\mathrm{m} \Sigma \mathrm{nt}=1 \mathrm{v} \times \mathrm{c})-(\text { Ед }+ \text { Еб }+ \text { Ебл })):(\text { Ед }+ \text { Еб }+ \text { Ебл })
$$

$\mathrm{m}$ is the total number of tourists who have visited the event;

$\mathrm{n}$ is the number of surveyed tourists;

$\mathrm{v}$ is the probability of purchasing a particular service/product;

$\mathrm{c}$ is the average amount of expenses per tourist.

2. A multiplier effect that takes into account direct, indirect and induced expenses. A broader notion of the tourists' expenses involves defining a set of direct and indirect expenses. To do this, we use the multiplier theory proposed by D. Keynes:

$$
\begin{aligned}
& \mathrm{m}=1:(1-\mathrm{c}) \\
& \mathrm{c}=\Delta \mathrm{C}: \Delta \mathrm{Y}
\end{aligned}
$$

where: $m$ is the multiplication factor, $c$ is the marginal propensity to consume; $\Delta C$ is the growth of consumprion, $\Delta Y$ is the revenue growth.

In this case, the condition $0<\mathrm{c}<1$ is met.

Based on this theory, techniques have been developed to determine aggregate efficiency, taking into account direct and indirect expenses from tourists in a particular destination, which can be used for eventive measures (Fig. 2). 


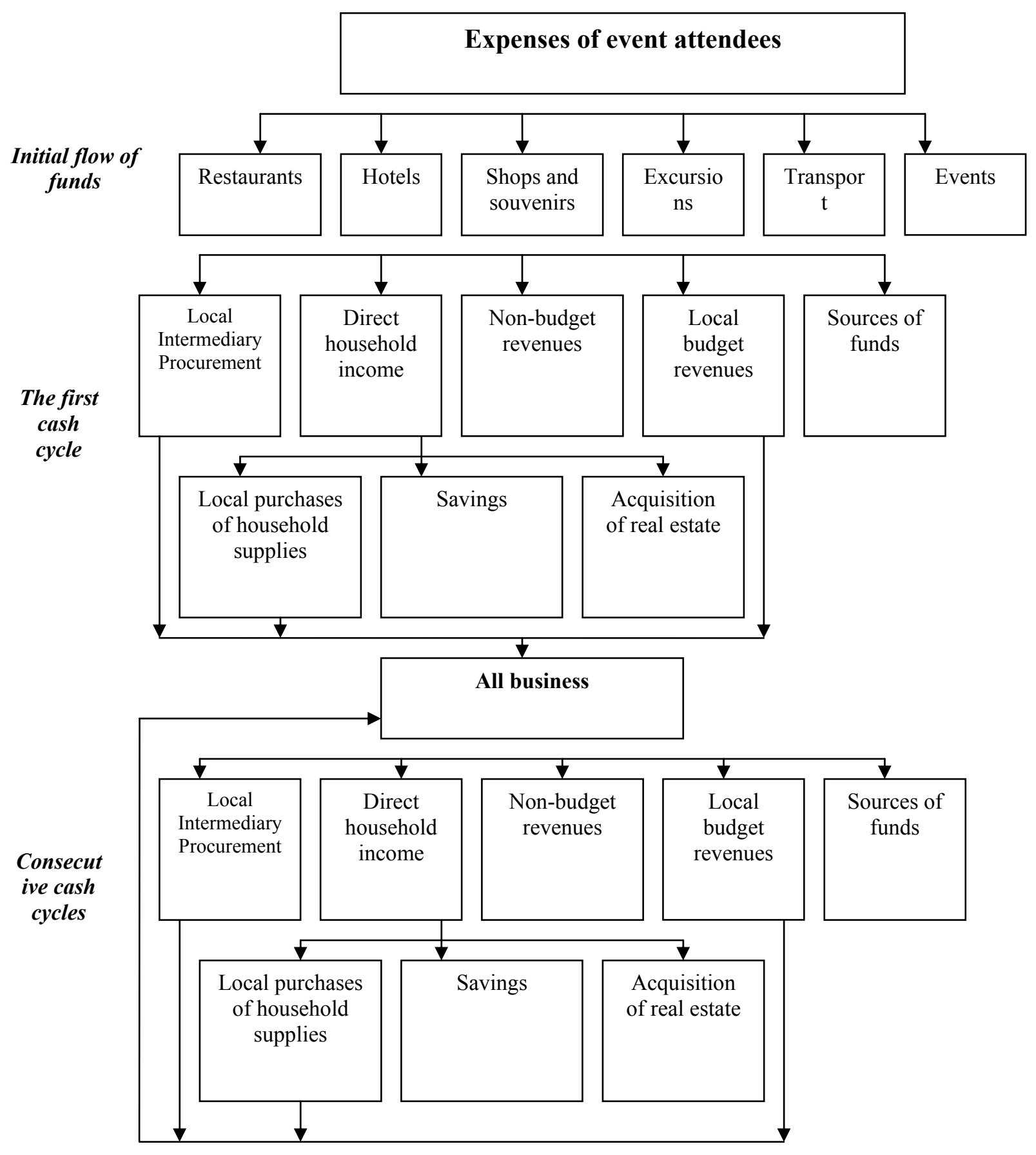

Fig. 2. Illustration of the multiplier effect of the events

Source: modified by the author on the basis of [8, p. 19]

In his research D. Bulin together with co-authors N. Miru, G. Gheorghe [6], as well as A. Okhrimenko [5] proposed the following method of calculating the multiplier effect:

$$
\mathrm{Me}=(\mathrm{ID}+\mathrm{IID}+\mathrm{II}): \mathrm{ID}
$$

where: $M e$ is the multiplier effect of eventive measures; $I D$ are the direct incomes from events; IID are the indirect incomes from events; II are the induced revenues from the eventive measures.

The mentioned dependence can also be presented taking into account the investments and the specifics of the event:

$$
\mathrm{Me}=(\mathrm{ID}+\mathrm{IID}+\mathrm{II}+\mathrm{CI}+\mathrm{GCS}-\mathrm{GI}-\mathrm{L}): \mathrm{ID}
$$

where: CI - investments of business structures for eventive measures; GCS - government expenditures for eventive measures; GI - imported goods at indirect expenses; L - other sources of funds (prize fund). 
When calculating the multiplier effect, it is also necessary to take into account the outflow of funds from the destination at the expense of the cost of the prize fund, imported goods and more.

Other formats for determining the cost-effectiveness of eventive measures that may take into account, for example, the interests of particular stakeholders, specific sources of costs, periods of events gathering, the scope of these events, etc. Thus, in particular, it is possible to conduct studies that determine the effectiveness of mega-events (large-scale events) for two countries (between two countries). At the same time, it should be noted that in Ukraine and Kyiv in particular, large-scale events of the European level have been carried out in recent years: European Football Championship (8 June - 1 July 2012), Eurovision (7-13 May 2017), finals of UEFA Champions League (26 May 2018 ).

Therefore, in order to determine the cost-efficiency of mega-events the scientists J. Fourie and M. SantanaGallego [12, p. 1365] proposed to use a gravity model, based on the bilateral flow (in this situation - the arrival of tourists) between the two countries. In order to determine the cost-effectiveness of the eventive measures, the amount of GDP, GDP per capita, the distance between the two countries, and a set of other factors such as a common border, a common language, a common currency or other common mental ties are taken into account.

$$
\begin{array}{ll} 
& \beta 0+\beta 1 \text { Ln Tradeijt }+\beta 2 \text { Ln GDPpcit }+\beta 3 \text { Ln GDPpcjt } \\
\text { Ln } & +\beta 4 \text { Ln Popit }+\beta 5 \text { Ln Popjt }+\beta 6 \text { Ln PPPijt } \\
\text { Touijt }= & +\beta 3 \text { Ln Distij }+\beta 4 \text { Ln Langij }+\beta 5 \text { Borderij }+\beta 6 \text { Ln Colonyij } \\
& +\beta 7 \text { CUij }+{ }^{\prime} \eta^{\prime} \text { Eit }+\gamma \mathrm{i}+\delta \mathrm{j}+\lambda \mathrm{j}+\text { uijt }
\end{array}
$$

where: $L n$ is the natural logarithm, indicating: $\mathrm{i}$ - country of destination, $\mathrm{j}$ - country of origin, and $\mathrm{t}$ - time; the dependent value of Touijt is the number of tourists who arrived in country $i$ from country $j$ in year $t$; Tradeijt is the real bilateral trade in goods and services as the sum of exports and imports between countries $i$ and $j$; GDPpcit and GDPpcjt is the real GDP per capita of $i$ and $j$ countries; Popit and Popjt are the populations of countries $i$ and $j$ respectively; Distij is the distance between the capitals of countries $i$ and $j$; PPPijt is the relative cost of living in the country of destination with respect to the source of origin (using the PPP conversion factor); Langij is a marker variable that is common if the country of origin and the country of destination have a common language and zero in the other; Borderij is double if the country of origin and the country of destination have a common land border and otherwise it's equal to zero; Colonyij is a marker variable that is common if there were ever colonial relations between the countries of a given pair, and CUij is a marker variable referring to a monetary union that assumes a value of 1 if both countries of the pair have a common currency, otherwise it's equal to $0 ; E^{\prime}$ is a vector of artificial variables associated with mega events; this variable will be determined depending on which hypothesis is tested; $\beta 0$ is a constant, $\gamma \mathrm{i}$ is the destination of fixed effects, $\delta \mathrm{j}$ is the origin of fixed effects, $\lambda \mathrm{j}$ are fixed effects, and uijt is the duration of an event.

The calculations of the effectiveness of mega-events between the two countries for Ukraine under this gravity model can be done for the upcoming events: International Choral Competitions - 2021, meetings of the United Nations World Tourism Organization (UNWTO), meetings of the European Bank for Reconstruction and Development, European Games and others.

Along with the positive consequences of the eventive measures, in order to prevent problems, the negative impacts should also be taken into account. In particular, the studies by W. Norman and S. Backman, K. Backman [16], as well as H. Preuss [17] emphasize this problem. To determine the negative economic impact of the event, it is possible to use the method of H. Preus [17, p. 284], where the economic consequences for the "victims" of the events are determined by the ratio:

$$
\Delta \mathrm{Y}=\mathrm{xa}-\mathrm{xb}-\Delta \mathrm{xk}-\Delta \mathrm{xHG}
$$

The economic impact $(\Delta Y)$ on people affected by regional events can be described by the cumulative consumption of all additional persons (xa) in the city/ region, with the exception of those forced to leave the city due to the event (opportunity cost) (xb) plus change in endogenous resident consumption $(\Delta \mathrm{xk})$ and change in exogenous visitor consumption that would in any case be in the city $(\Delta \mathrm{xHG})$. In more detail, the number of days $(\mathrm{t})$, the number of visitors $(\mathrm{x})$ and the consumption period $(\mathrm{CP})$ can describe exports $(\mathrm{x})$ in equation 10.

$$
\Delta \mathrm{Y}=\mathrm{CPa} \times \mathrm{ta} \times \mathrm{xa}-\mathrm{CPb} \times \mathrm{tb} \times \mathrm{xb}+\Delta \mathrm{CPK} \times \mathrm{tK} \times \mathrm{xK}+\Delta \mathrm{CPH}, \mathrm{G} \times \mathrm{t} \mathrm{H}, \mathrm{G} \times \mathrm{x} \mathrm{H}, \mathrm{G} \mathrm{G}
$$

The equation shows the change in impact $(\Delta Y)$ caused by the change in consumption of different groups of individuals. Residents $(\mathrm{K})$ consumption during the event can be offset in the aftermath of the event by savings or additional consumption.

Conclusions from this study and prospects for further exploration in this area. Tourism, as an economic sector, is an important catalyst for a positive impact on other sectors. The expansion of types and forms of tourism contributes 
to the large-scale growth of its effects. Eventive tourism, based on event management, is currently dynamically developing and quite popular (without taking into account the particular force majeure circumstances characterized by short-term determinants). In this context, determining the cost-effectiveness of the eventive measures is important for various stakeholders: state, local, business, public and community organizations. It is determined that the effectiveness of these measures can be determined by different methods and necessary for the stakeholders. The main one is the ratio of income to expenses. Further studies require calculations of the economic impact of specific measures. In addition, the decisive requirements for them are reliable statistical information.

\section{References.}

1. Alekseeva O. (2011). Podkhod k oszenke vliania sobytiinykh meropriatii na tkonomiku regiona, Upravlenie ekonomicheskimi sistemsmi elektronnii nauchnyi zhurnal, 8(23).

2. Bobina N.V. (2016). Organisazionno-ekonomicheskie aspekty rasvitia olimpiiskogo turisma i ego vlianie na prinimaiuschuu dettinaziu : dis ... kand. ekonomicheskikh nauk. Sochinskii gosudarstvennii universitet. Sochi.

3. Honcharov V.V. (2009). Turistskii multiplikator kak instrument regionalnogo upravlenia // Vestnik INZHEKON, 1(28), 277-280.

4. Okhrimenko, A. H. (2019), Natsional'na turystychna systema [National tourism system], Kyivs'kyj natsional'nyj torhovel'no-ekonomichnyj universytet, Kyiv, Ukraine.

5. Bulin, D. (2014). The impact of tourism industry in the economy. The case of black sea region countries, Knowledge Horizons - Economics, Vol. 6 (2), P. 74-79.

6. Burgan, B. and Mules, T. (2001). Reconciling Cost - Benefit and Economic Impact Assessment for Event Tourism. Research Article. https://doi.org/10.5367/000000001101297892 (Accessed 08 April 2020).

7. Crompton, J. L. (1995). Economic Impact Analysis of Sports Facilities and Events: Eleven Sources of Misapplication, Journal of Sport Management, 9, 14-35

8. Crompton, J. L. Measuring the Economic Impact of Festivals and Events: Some Myths, Misapplications and Ethical Dilemmas, Fest Mgmt \& Evnt Tour, 1994, Vol. 2(9), 33-43. https://doi.org/10.1123/jsm.9.1.14. (Accessed 08 April 2020).

9. Daniels, M.J. and Norman, W.C. (2010). Estimating the Economic Impacts of Seven Regular Sport Tourism Events, 214-222 https://doi.org/10.1080/1477508032000161528. (Accessed 08 April 2020).

10. Davidson, L. S. and Schaffer, W. A. (1980). A discussion of methods employed in analyzing the impact of short-term entertainment events, Journal of Travel Research, 18, 12-16.

11. Fourie, J. and Santana-Gallego M. (2011). The impact of mega-sport events on tourist arrivals, Tourism management, 23, 1364-1370 https://doi.org/10.1016/j.tourman.2011.01.011. (Accessed 08 April 2020).

12. Hodur, N. M. and Leistritz F. L. (2006) Estimating the Economic Impact of Event Tourism, Journal of Convention \& Event Tourism, 8(4), 63-79, DOI: 10.1300/J452v08n04_05. (Accessed 08 April 2020).

13. Kurtzman, J. (2006). Economic impact: sport tourism and the city, P. 47-71. https://doi.org/10.1080/14775080500101551. (Accessed 08 April 2020).

14. Marsh, J. S. (1984). The economic impact of a small city annual sporting event: An initial case study of the Peterborough Church League Atom Hockey Tournament. Recreation Research Review, 11.

15. Norman, W., Backman, S. and Backman, K. (2002). The changing face of tourism impact analysis, Paper given at the National Extension Tourism Conference, Traverse City.

16. Preuss, H. (2006). The Economic Impact of Visitors at Major Multi-sport Events, European Sport Management Quarterly, 281-301 . https://doi.org/10.1080/16184740500190710. (Accessed 08 April 2020).

17. Rose, A. K. and Spiegel, M. M. (2010). The Olympic effect, Economic Journal, August 23. http://faculty.haas.berkeley.edu/arose/OlympR2long.pdf. (Accessed 08 April 2020). 